\title{
Adequacy of energy, zinc and selenium intakes among adult inpatients receiving total naso-gastric tube feeding admitted to a Copperbelt province Referral Hospital, in Ndola District, Zambia
}

\author{
Murambiwa Nyati ${ }^{*}$ (D) Irene Ogada ${ }^{1}$ and Christopher Nyirenda ${ }^{2}$
}

\begin{abstract}
Background: Poor hospital outcomes among adult patients admitted to hospitals have been attributed to inadequate nutrient intake and progressive disease conditions. The purpose of this study was to determine the adequacy of the intake of energy, zinc and selenium among adult inpatients receiving hospital prepared total nasogastric blended tube feeding (NGTF).

Methods: This was a cross-sectional study that adopted quantitative approaches in data collection, analysis and presentation. A comprehensive sample of 113 adult patients, 20-65 years of age who had been on total NGTF in the previous $24 \mathrm{~h}$ participated in the study. Nutrient adequacy for individual patients was established using the Harris Benedict equation (HBE) and the European Society for Clinical Nutrition and Metabolism (ESPEN) daily recommendations for zinc and selenium intakes. A researcher-administered questionnaire was used to collect data on socio-economic and medical characteristics. Fourteen pairs of hospital prepared NGTFs were sampled weekly for 3 months and analysed for total energy, carbohydrate, protein, fat, zinc and selenium content using AOAC international methods.

Results: Mean total energy, zinc and selenium content for NGTF was $126.9 \pm 67.0 \mathrm{Cal} / 100 \mathrm{ml}(64.6 \%$ carbohydrate, $23.1 \%$ protein and $12.3 \%$ fat), $0.13 \pm 0.01 \mathrm{mg} / 100 \mathrm{ml}$ and $0.09 \pm 0.02 \mu \mathrm{g} / 100 \mathrm{ml}$ respectively and this content varied significantly among the paired samples $(p<0.05)$. Mean volume intake of NGTF was $257.1 \pm 273.0 \mathrm{ml} /$ day given through scheduled gravity feeding. This resulted in a mean total energy intake of $326.5 \pm 346.7 \mathrm{Cal} /$ day $(5.5$ $\mathrm{Cal} / \mathrm{Kg} /$ day), mean carbohydrate intake of $210.9 \pm 223.9 \mathrm{Cal} /$ day, mean protein intake of $0.3 \mathrm{~g} / \mathrm{Kg} /$ day, with zinc at 0 . $34 \pm 0.24 \mathrm{mg} /$ day and selenium at $0.23 \pm 0.24 \mu \mathrm{g} /$ day. The mean total energy, protein, zinc and selenium intakes were significantly lower than the recommended values $(p<0.05)$. All participants had inadequate zinc and selenium intakes while only $0.88 \%$ had adequate energy intake.

Conclusion: In this study, there was evidence of inconsistent supply of energy, carbohydrates, protein, fat, zinc and selenium to patients on naso-gastric tube feeds. Since inconsistency in supply of nutrients is associated with poor hospital outcomes, it is recommended that commercial tube formulas with known and predictable nutrient amounts be used.
\end{abstract}

Keywords: Naso-gastric tube feeding, Nutrient adequacy, Nutrient intake, Zinc, Selenium, Energy

\footnotetext{
* Correspondence: murambiwan@yahoo.co.uk

1 Department of Food, Nutrition and Dietetics, Kenyatta University, P O Box

43844, Nairobi, Kenya

Full list of author information is available at the end of the article
} 


\section{Background}

The intake and adequacy of energy, zinc, and selenium among patients admitted to hospitals have been shown to be related to their morbidity and mortality [1]. Adequate provision of these nutrients can improve patient nutrition and health outcomes [2]. Energy deficiency has been shown to be common among hospitalized patients [3]. This often has resulted in muscle wasting, poor response to therapy and generally poor hospital outcomes among admitted patients [3]. Zinc deficiency has also been reported among elderly hospitalized patients. Significant proportions among admitted patients with zinc deficiency have reported medical complications such as respiratory infections, cardiac failure, delayed wound healing, altered immunological functions, diarrhea, anemia and depression [4]. Among micronutrients, selenium has also been shown to have anti-oxidant functions through the synthesis of seleno proteins that might contribute to protection against cardiovascular diseases, degenerative diseases, cancer and strengthening of the immune system [5]. Deficiency of selenium is common in areas with lower selenium content in their soils. The human body lacks storage system mechanism to easily replenish zinc and selenium in case of a deficiency [6]. Daily intakes of essential micronutrients in recommended amounts in health and disease is important to maintain optimal nutrition status. Most studies on adequacy of energy, zinc and selenium intakes have been conducted in developed countries and majority have reported inadequate intake among admitted patients [3]. In sub Saharan Africa in particular Malawi, a study estimated more than $50 \%$ of households were at risk for energy, zinc, calcium and selenium deficiencies due to low dietary intake [7]. Studies on nutrient intake of energy, zinc and selenium among hospitalized patients' remains scarce in the sub Saharan Africa, and in particular Zambia.

Naso-gastric tube feeding (NGTF) has been supported by various enteral and parenteral nutrition societies globally to enhance nutrient delivery to patients with a functional gut, facing difficulties eating and meeting their daily nutrient targets $[1,2,8]$. Tube feeding in hospitals has evolved over the past years, from feeding of milk, meat broth, raw eggs, to blenderized combination of foods, and now commercial tube formulas (CTF) [8]. The European Society for Clinical Nutrition and Metabolism (ESPEN), American Society for Enteral and Parenteral Nutrition (ASPEN), among other organizations, have overseen the transformation of traditional hospital prepared naso-gastric tube feeds to CTF $[1,2]$. Commercial tube formulas have been shown to have an added advantage of having known standard nutrient compositions [9]. Based on various reported studies, CTF have been recommended for naso-gastric tube feeding in hospitals $[1,10,11]$. This is because studies have found that unlike CTF, hospital prepared tube feeds are associated with inconsistent delivery of macronutrients and micronutrients
[12-14]. In the developed world, the use of CTF among patients on NGTF has widely been documented. In contrast, most low income countries use hospital prepared tube feeds for management of their patients [14]. Further, administration of NGTF in the developed world has been documented to follow standard operating procedures unlike hospitals in the sub-Saharan Africa, and Zambia in particular [15]. In studies conducted in the Philippines and Saudi Arabia, nutrient deficiencies among hospitalized adults receiving hospital prepared naso-gastric blended tube feeds were reported $[16,17]$. Micronutrient deficiencies, particularly zinc and selenium were reported to be common among patients with low energy intake $[17,18]$. These nutrient deficiencies were also shown to result in poor hospital outcomes $[18,19]$.

Public hospitals in Zambia are the main health care service providers [20]. Patients fed through NGTF in these public hospitals are managed on hospital prepared feeds with unknown nutrient content which results in longer hospital stay therefore increasing their risk for hospital malnutrition [21]. Malnourished patients take longer to heal, this results in increased use of the scarce personal and hospital resources which in turn affects productivity of individuals and the nation as a whole [22]. These NGTF used in Zambian public health hospitals are mainly prepared from various foods ranging from corn flour, rice flour, groundnut flour, milk, eggs and soy flour [21]. Further, in Zambia, there is scarce literature on locally developed standard operating procedures for NGTF by the Ministry of Health and various public health facilities [20]. Ultimately, the current practice of enteral nutrition in Zambia might not be enhancing progress towards achieving the Zambian Vision 2030 that aims to provide quality health care. Optimal nutritional support for all patients is a key component in attaining this vision [21]. There is limited literature in sub-Saharan Africa and in particular Zambia on the energy, zinc and selenium intakes and adequacy among patients receiving total naso-gastric blended tube feeds [21]. It is against this background that the study aimed to assess adequacy of total energy, carbohydrate, protein, fat, zinc and selenium intakes among patients receiving total hospital prepared blended naso-gastric tube feeding.

\section{Scope of the study}

The study focused on energy, zinc and selenium intake and adequacy among patients admitted to a referral hospital who received hospital prepared total naso-gastric blended tube feedings and did not consider other micronutrients.

\section{Operational definitions}

In this study the following terms meant;

Adults: Inpatients 20 to 65 years of age. 
Naso-gastric Feed: Any form of food prepared in the hospital given to patients through the naso-gastric tube.

Nutrient Adequacy: Patients' attainment of the minimum recommended requirement by European Society for Clinical Nutrition and Metabolism (ESPEN) set standards of zinc and selenium for patients on total naso-gastric feeding. Energy adequacy is the attainment of 90 to $110 \%$ of energy requirement as determined by Harris-Benedict Equations.

Total Naso-gastric Feeding: Patients fed exclusively through naso-gastric route in the previous $24 \mathrm{~h}$.

\section{Methods}

\section{Research design, period and location}

The study adopted a cross-sectional analytical design with quantitative techniques in data collection, analysis and presentation [23]. The design was suitable in establishing associations between total energy, protein, carbohydrate, fat, zinc and selenium intakes and their nutrient adequacy among adult patients receiving total nasogastric tube feedings. The study was conducted from August to November 2015.

The study was conducted at a referral hospital in the Copperbelt province in Ndola district of Zambia. It is the second largest public tertiary level hospital in Zambia with 851 bed capacity located in Ndola District [24]. The hospital offers curative services for adults through in-patient departments (medical wards, intensive care unit [ICU], surgical wards, emergency/ambulatory, and obstetrics /gynecology wards) and out-patient departments [21].

\section{Study populations}

The study targeted adult inpatients 20 to 65 years of age receiving hospital prepared total naso-gastric blended tube feeding admitted to the hospital. The sampling frame was estimated at 150 patients for the three months (14 weeks) period that the study would be undertaken, based on the estimated average of 50 patients per month on total nasogastric tube feeding as reported by the Health Information Office (HIO) of Ndola Central Hospital [21]. All of the study participants were non-ambulant and drawn from two female medical wards, two male medical wards, as well as the ICU.

Consenting adult patients, 20 to 65 years of age receiving hospital prepared total naso-gastric blended tube feeding in the previous $24 \mathrm{~h}$ and admitted to medical wards, and the intensive care unit, were eligible to participate in the study. The study's exclusion criteria were patients receiving naso-gastric tube feeds prepared from outside the hospital kitchen. This is because feeds prepared from outside the hospital would not be analysed for nutrient content and could have affected the results if included.

\section{Sampling technique and sample size}

The referral hospital was purposively sampled among the four main tertiary hospitals in the country because of its speciality in treating adult illnesses. Further, medical wards and the intensive care unit were purposively sampled because they admitted the most participants receiving naso-gastric tube feedings [21].

For selection of individual study participants, comprehensive sampling was adopted, where all adult patients who satisfied the inclusion criteria and consented to participate were included [25, 26]. A total of 123 patients were eligible to participate in the study and 117 patients provided consent. Four participants had missing data and were subsequently excluded from the analysis. A total of 113 patients had information fully collected and comprised the sample size of the study.

\section{Socio-economic and medical characteristics of adult inpatients receiving total naso-gastric tube feeding}

One time face-to-face interviews were conducted at the wards with participants to obtain information on socioeconomic characteristics. These interviews were guided by a researcher-administered questionnaire. For those patients who could not speak, only close relative who lived with them in the same household answered on their behalf.

A researcher-administered questionnaire was also used to collect medical characteristics on participants. Provisional admission diagnosis and length of stay data were collected by the researcher from individual medical files to the researcher-administered questionnaire. Clinicians attending to patients determined individual Glasgow Coma Scale (GCS) scores for participants and recorded them in the researcher-administered questionnaire.

\section{Naso-gastric tube feeds collection, tracking and analysis}

Fourteen (14) pairs of NGTF samples were collected every Wednesday, for 14 weeks ( 3 months, 1 week). Uniquely coded $20 \mathrm{ml}$ transparent sterile vacutainer trace elements tubes (Vacutainer Systems Europe B.P No. 37-38241 Meylan Cedex-France, Becton Dickson) were used to collect these samples from the hospital kitchen's preparation vessel. The samples were stored temporarily on dry ice at $0{ }^{\circ} \mathrm{C}$ then transferred to a freezer for longer storage at less than $-20^{\circ} \mathrm{C}$ within $3 \mathrm{~h}$ of collection time and finally transported to the laboratory for analysis below $0{ }^{\circ} \mathrm{C}$ [27]. A laboratory form was used to record and track the samples. The form had information on time of food sampling, time of storage and volume collected. On the same form, results of nutrient content were reported for each sample. The volume of NGTF provided to the participants in the 
previous $24 \mathrm{~h}$ were calculated from the patients' feeding charts in the medical files. The volumes aggregated per individual patient were used to determine the individual's energy, zinc and selenium intakes.

Fourteen paired samples of naso-gastric feeds were analysed at ARC-Irene Analytical Services laboratory in South Africa to determine nutrient content. Nutrient analyses were conducted using the official analytical methods of Association of Analytical Chemists (AOAC): Kjeldahl for protein, acid hydrolysis for fat, computation of difference for carbohydrate, and inductively coupled plasma-atomic emission spectrometry for zinc and selenium [28].

\section{Research instruments}

The researcher-administered questionnaire and data collection procedures were pre-tested at a similar referral hospital, prior to the main study. The researcheradministered questionnaire was used to collect information on socio-economic and medical characteristics. The questions used to determine the socio-economic characteristics were adopted from the validated Zambia Demographic and Health Survey questionnaires (ZDHS) [20]. Medical characteristics were developed after an intensive discussion with the clinicians for the facility. To enhance validity, the NGTF samples were collected and tested using an accredited laboratory in South Africa (ARCIrene Analytical Laboratory).

The procedures employed in pre-testing the instruments were identical to those used in the main study, with participants of similar characteristics. A total of 10 patients participated in the pre-test and they were not included in the main study. The test and re-test method was used to evaluate the reliability of the researcher- administered questionnaire. During the pretest, data were collected twice from the same participants within an interval of three days and analysed. A correlation coefficient of 0.88 (95 \% C.I; 0.78-0.95) was achieved between the two sets of data. A correlation coefficient of above 0.7 is usually considered adequate [26]. By obtaining two random samples, the reliability of the NGTFs was also enhanced.

\section{Data analyses}

Statistical Package for Social Sciences (SPSS) version 20.0 was used for data entry, cleaning, and analysis. Descriptive statistics such as frequencies, means and standard deviations were used to describe the study population in terms of socio-economic and medical characteristics as well as the mean nutrient (total energy, fat, carbohydrate, protein, zinc and selenium) content of the naso-gastric tube feeds.

The naso-gastric feeds samples were analyzed for their variation using two way $t$-test, while nutrient adequacy was determined by comparing nutrient intake to the two standards using paired $t$-test.

To determine the individual energy requirement of each participant, the Harris-Benedict equations (HBE) (for females; Basal Energy Expenditure $(\mathrm{BEE})=655.1+$ [9.6weight $]+[1.8$ height $]-[4.7$ age $]$ and males; $\mathrm{BEE}=$ $66.5+[13.8$ weight $]+[$ [height $]-[6.8$ age $]$ ) with individual stress factor) were applied [28]. Energy intakes of 90 to $110 \%$ of the calculated requirements was considered adequate [29]. For zinc and selenium, the ESPEN minimum daily requirements (Zinc [11-19 $\mathrm{mg} /$ day] and Selenium $[20-70 \mu \mathrm{g} /$ day $]$ ) of adults on enteral nutrition were compared to participants' intake during the previous $24 \mathrm{~h}$ [30].

\section{Results}

Participants' socio-economic and medical characteristics A total of 113 inpatients with 82 admitted from the medical wards and 31 admitted from the intensive care unit had their data fully collected and analysed.

The mean age of participants was $42.6 \pm 11.4$ years (Table 1). About a third (34.4\%) of the participants were 40 to 49 years of age with the majority (73.5\%) were under the age of 50 years. More than half $(57.5 \%)$ of the participants were females and the same percentage of participants were married. Slightly less than a third (30.1\%) had no formal education with only $4.4 \%$ having tertiary education. Almost half (46.9\%) of the participants were casual workers with only $14.2 \%$ in formal employment. Only $16.8 \%$ were self-employed, $6.2 \%$ were housewives and while $3.5 \%$ were students. A majority (76.1\%) of participants had a monthly income of less than 1000 Kwacha (K); 100 United States dollars (USD). Few (3.5\%) earned above K5000 (500USD).

The provisional admission diagnosis for most patients was septic shock (37.2\%) followed by cardiac and central nervous diseases accounting for $17.7 \%$ (Table 2). Other diagnosis were endocrine diseases (15.9\%), renal $(9.7 \%)$ and head injuries representing $7.1 \%$. Few cases consisted of spinal cord injury and burns with only $2.6 \%$ and $1.8 \%$ respectively. All patients did not have their nutrition diagnosis indicated in their medical records. The level of consciousness varied among participants, with an overall mean Glasgow coma scale (GCS) score of $10.5 \pm 4.8$ points. A total of 26 participants $(40.7 \%)$ were fully conscious with their GCS at 15 points. Further, $23 \%$ had their GCS below 5 points with $36.3 \%$ in semi-conscious states with GCS from 14 to 5 points.

Majority $(52.2 \%)$ of participants had stayed for over 7 days while $21.2 \%$ were less than 3 days old in hospital admission. 
Table 1 Socio-economic characteristics of patients on total naso-gastric feed

\begin{tabular}{|c|c|c|}
\hline Characteristic & $N=113$ & Mean \pm SD \\
\hline Age in complete years & $\mathrm{n}(\%)$ & $42.6 \pm 11.4$ \\
\hline $20-29$ & $20(17.7)$ & \\
\hline $30-39$ & $24(21.2)$ & \\
\hline $40-49$ & $39(34.4)$ & \\
\hline $50-59$ & $20(17.7)$ & \\
\hline $60-65$ & $10(8.8)$ & \\
\hline Total & 113 & \\
\hline \multicolumn{3}{|l|}{ Sex } \\
\hline Male & $48(42.5)$ & \\
\hline Female & $65(57.5)$ & \\
\hline Total & 113 & \\
\hline \multicolumn{3}{|l|}{ Marital status } \\
\hline Married & $65(57.5)$ & \\
\hline Single & $21(18.6)$ & \\
\hline Divorced & $16(14.2)$ & \\
\hline Widowed & $11(9.7)$ & \\
\hline Total & 113 & \\
\hline \multicolumn{3}{|l|}{ Level of education } \\
\hline None & $34(30.1)$ & \\
\hline Not completed primary & $41(36.3)$ & \\
\hline Completed primary & $5(4.4)$ & \\
\hline Not completed secondary & $13(11.5)$ & \\
\hline Completed secondary & $15(13.3)$ & \\
\hline Attended tertiary & $5(4.4)$ & \\
\hline Total & 113 & \\
\hline \multicolumn{3}{|l|}{ Occupation } \\
\hline Casual worker & $53(46.9)$ & \\
\hline House wife & $7(6.2)$ & \\
\hline Formal employment & $16(14.2)$ & \\
\hline Self-employment & $19(16.8)$ & \\
\hline Student & $4(3.5)$ & \\
\hline Other & $14(12.4)$ & \\
\hline Total & 113 & \\
\hline \multicolumn{3}{|l|}{ Monthly income } \\
\hline$<1000$ Kwacha & $86(76.1)$ & \\
\hline 1000-2000 Kwacha & $14(12.4)$ & \\
\hline 2001-5000 Kwacha & $9(8.0)$ & \\
\hline > 5000 Kwacha & $4(3.5)$ & \\
\hline Total & 113 & \\
\hline
\end{tabular}

Note: $1000 \mathrm{Kwacha}$ is equivalent to 100 USD
Table 2 Medical characteristics of patients on naso-gastric tube feeding

\begin{tabular}{lc}
\hline Characteristic & $N=113$ \\
\hline Provisional admission diagnosis & $\mathrm{n}(\%)$ \\
Head injury & $8(7.1)$ \\
Spinal cord injury & $3(2.6)$ \\
Cardiac/CNS diseases & $20(17.7)$ \\
Endocrine diseases & $18(15.9)$ \\
Major surgery & $9(8.0)$ \\
Sepsis & $42(37.2)$ \\
Burns & $2(1.8)$ \\
Renal diseases & $11(9.7)$ \\
Total & 113 \\
Glasgow coma scale mean \pm SD & $10.5 \pm 4.8$ \\
Glasgow coma scale categories & \\
$<5$ & $26(23.0)$ \\
$5 \geq x<11$ & $21(18.6)$ \\
$12 \geq x<15$ & $20(17.7)$ \\
15 & $46(40.7)$ \\
Total & 113 \\
Length of stay (LOS) & \\
$<3$ days & $24(21.2)$ \\
Total days & $30(26.5)$ \\
\hline & $59(52.2)$ \\
\hline & $113(100.0)$ \\
\hline & \\
\hline &
\end{tabular}

\section{Energy, zinc and selenium content of hospital prepared naso-gastric tube feeds}

The nutrient composition for the 14 pairs of nasogastric feed samples showed a total energy content of $126.9 \pm 67.0 \mathrm{Cal}$ per $100 \mathrm{ml}$ (Table 3). Further, the nutrient mean contents were tested for differences using two sided sample $t$-test and the results showed significant differences in total energy ( $\mathrm{t}=37.19, p=0.000)$, carbohydrate $(\mathrm{t}=24.92, p=0.000)$, protein $(\mathrm{t}=10.82, p=0.000)$,

Table 3 Carbohydrate, protein, fat, Zinc and Selenium content of naso-gastric feed

\begin{tabular}{lrrrc}
\hline Nutrient $N=14$ & $\begin{array}{l}\text { Mean } \\
\text { grams }(\mathrm{g}) \\
\text { per } 100 \mathrm{ml}\end{array}$ & $\begin{array}{l}\text { Mean } \pm \text { SD } \\
\text { Cal per } \\
100 \mathrm{ml}\end{array}$ & $\begin{array}{l}\text { Percentage } \\
\text { of energy } \\
\text { content }\end{array}$ & $\begin{array}{l}\text { Two way } \\
\text { sample } t \text {-test } \\
p \text {-value }\end{array}$ \\
\hline Carbohydrate & $\begin{array}{r}20.51 \pm 8.25 \\
82.0 \pm 33.0\end{array}$ & 64.6 & $0.000^{*}$ \\
Protein & $7.34 \pm 5.75$ & $29.3 \pm 23.0$ & 23.1 & $0.000^{*}$ \\
Fat & $1.74 \pm 1.20$ & $15.6 \pm 11.0$ & 12.3 & $0.000^{*}$ \\
Total energy & & $126.9 \pm 67.0$ & 100.0 & $0.000^{*}$ \\
content (Cal) & & & & $0.013^{*}$ \\
Zinc (mg) & $0.13 \pm 0.01$ & & & $0.001^{*}$ \\
Selenium $(\mu \mathrm{g})$ & $0.09 \pm 0.02$ & & & \\
\hline
\end{tabular}

*Significant at $p<0.05$ 
fat $(\mathrm{t}=9.16 . p=0.000)$, zinc $(\mathrm{t}=2.85, p=0.013)$ and selenium $(\mathrm{t}=4.52, p=0.001)$ contents among the samples taken. This implies that the nutrient content of the naso-gastric feeds were unpredictable and varied. Most of the energy was from carbohydrates (64.6\%), with $12.3 \%$ from fat and $23.1 \%$ from protein. Mean content for zinc and selenium were $0.13 \pm 0.01 \mathrm{mg}$ per $100 \mathrm{ml}$ and $0.09 \pm 0.02 \mu \mathrm{g}$ per $100 \mathrm{ml}$ respectively.

\section{Nutrient intake among patients receiving total naso- gastric feeding}

The mean volume of naso-gastric feedings provided to participants was $257.1 \pm 273.0 \mathrm{ml} /$ day and this provided a total mean energy intake of $326.5 \pm 346.7 \mathrm{Cal} /$ day $(5.5 \mathrm{Cal} /$ $\mathrm{Kg} /$ day) (Table 4). Over two thirds $(210.9 \pm 223.9 \mathrm{Cal} /$ day $)$ of energy intake was accounted for by carbohydrate, with fat providing $40.2 \pm 42.7 \mathrm{Cal} /$ day, and $75.4 \pm 80.1 \mathrm{Cal} /$ day ( $0.3 \mathrm{~g} / \mathrm{Kg} /$ day) from protein. The overall mean intake for zinc and selenium intakes were $0.34 \pm 0.24 \mathrm{mg} /$ day, $0.23 \pm$ $0.24 \mu \mathrm{g} /$ day respectively. It is important to note that nasogastric prescriptions for tube feeding volumes were not found in all participants medical files. Scheduled feeding (bolus feeding) was used for the administration of nasogastric feeds to all participants.

\section{Nutrient adequacy among patients on naso-gastric feed}

Among the participants, only one patient $(0.88 \%)$ received adequate energy in the previous $24 \mathrm{~h}$ based on the Harris-Benedict daily energy (HBE) requirements (Table 5). Most of the participants (90.2\%) had energy intakes of less than $40 \%$ of their $\mathrm{HBE}$ requirements. Similarly, zinc and selenium intakes $(0.34 \pm 0.24 \mathrm{mg} /$ day and $0.23 \pm 0.24 \mu \mathrm{g} /$ day respectively) were inadequate (lower than ESPEN daily recommended intakes for patients on enteral nutrition) for all participants.

The mean intakes for all nutrients were significantly less than the mean requirement (paired $t$-test: total

Table 4 Mean volume and nutrient intake provided by NGTF in the previous $24 \mathrm{~h}$

\begin{tabular}{lccc}
\hline Nutrient & $\begin{array}{l}\text { Intake in } \\
\text { grams }(\mathrm{g}) \\
\text { in the } \\
\text { previous } \\
24 \mathrm{~h}\end{array}$ & $\begin{array}{l}\mathrm{N}=113 \\
\text { Mean energy intake } \\
\text { in the previous 24 h } \\
\text { mean } \pm \text { SD Cal }\end{array}$ & $\begin{array}{l}\text { Percentage } \\
\text { conergy } \\
\text { contribution }\end{array}$ \\
\hline $\begin{array}{l}\text { Mean total volume } \\
\text { intake (ml) }\end{array}$ & $257.1 \pm 273.0$ & \\
Carbohydrate & $52.7 \pm 55.99$ & $210.9 \pm 223.9$ & 64.6 \\
Protein & $18.9 \pm 20.0$ & $75.4 \pm 80.1$ & 23.1 \\
Fat & $4.5 \pm 4.7$ & $40.2 \pm 42.7$ & 12.3 \\
Total energy (Cal) & & $326.5 \pm 346.7$ & \\
Zinc (mg) & $0.34 \pm 0.24$ & & \\
Selenium $(\mu \mathrm{g})$ & $0.23 \pm 0.24$ & & \\
\hline
\end{tabular}

energy $p=0.012$, carbohydrate $p=0.010$, protein $p=$ 0.011 , fat 0.014 , zinc $p=0.017$ and selenium $p=0.019$ ).

\section{Discussion}

Most patients admitted to medical wards and the ICUs' are in a hyper-catabolic state resulting in increased energy and other nutrient needs resulting in malnutrition [28]. Short term stabilization of their medical condition is dependent on the type and timing of nutrition support administered [31]. The composition of blended foods used during the management of patients on NGTF determines how soon nutrient adequacy is attained [29].

This study adds to the evidence that hospital prepared NGTFs have varying and inconsistent nutrient content. Similar inconsistencies in hospital prepared naso-gastric feeds have been reported in the Philippines and Saudi Arabia for energy, zinc, selenium and other micronutrients $[12,14]$. The fact that carbohydrate content accounted for most of the energy provided followed by protein is not unique to this study. The ESPEN endorsed nutrient composition for standard high energy formulae for naso-gastric tube feeding indicates a supply of carbohydrate of 49 to $53 \%$, with protein at 20 and $30 \%$ [18]. Other findings in a meta-analysis showed carbohydrate accounting for over $50 \%$ of energy in NGTFs, followed by protein at $25 \%$ and then fat $[19,32]$ Further, zinc and selenium content being low and varied was reported in the same studies in which significant variation was seen in hospital prepared blended foods for NGTF $[12,14]$.

Feeding of patients with blended food for NGTF with unpredictable and inconsistent nutrient composition has serious outcome implications [33]. In a longitudinal study conducted on cancer patients, morbidity increased in patients that did not attain nutrient set targets [30]. Similarly, in the current study patients did not attain macronutrient or micronutrients targets, therefore their actual nutrient intake influence on their morbidity would be an interesting area to find out. Other studies found discrepancies between the expected and determined values for all nutrients in both hospital prepared blended NGTF but less discrepancy in Commercial Tube Formulas (CTF) [13-15]. Those studies recommended that CTF replace hospital prepared blended feeds because their nutrient content had limited variability. Studies conducted in the United States, Britain and the Philippines in which hospital prepared blended feeds and CTF were fed to critically ill patients showed remarkable improvement in patients on CTF $[13,17,30]$. The variations in hospital prepared blended feeds is what prompted ASPEN and ESPEN to set standards of feeding through administration of CTF $[1,3]$. Commercial tube feeds have been designed in different energy concentrations ranging from1.0 Cal $/ \mathrm{ml}$ to $5.0 \mathrm{Cal} / \mathrm{ml}$ [33]. Similarly, recommended protein content also ranges from 4 to $32 \%$ of the total energy [34]. Fat in commercial preparations ranges from 1 to 
Table 5 Comparison of nutrient intake and nutrient requirements (nutrient adequacy)

\begin{tabular}{|c|c|c|c|}
\hline \multirow[t]{2}{*}{ Nutrient } & \multirow{2}{*}{$\begin{array}{l}\text { Actual Nutrient intake } \\
\text { in previous } 24 \mathrm{~h} \\
\text { Mean } \pm \text { SD }\end{array}$} & \multirow{2}{*}{$\begin{array}{l}\text { Recommended nutrient } \\
\text { intake for } 24 \mathrm{~h} \text {. (HBE and } \\
\text { ESPEN requirement) } \\
\text { Mean } \pm \text { SD }\end{array}$} & \multirow{2}{*}{$\begin{array}{l}\text { Paired } t \text {-test } \\
p \text {-value }\end{array}$} \\
\hline & & & \\
\hline Carbohydrate (Cal/day) & $210.9 \pm 223.9$ & $970.1 \pm 144.7$ & $0.010^{*}$ \\
\hline Protein (Cal/day) & $75.4 \pm 80.1$ & $242.5 \pm 36.2$ & $0.011^{*}$ \\
\hline Fat (Cal/day) & $40.2 \pm 42.7$ & $404.2 \pm 60.3$ & $0.014^{*}$ \\
\hline Total energy intake (Cal/day) & $326.5 \pm 346.7$ & $1616.9 \pm 241.2$ & $0.012^{*}$ \\
\hline Zinc (mg/day) & $0.34 \pm 0.24$ & $15.0 \pm 12.23$ & $0.017^{*}$ \\
\hline Selenium ( $\mu \mathrm{g} /$ day) & $0.23 \pm 0.24$ & $55.0 \pm 45.56$ & $0.019^{*}$ \\
\hline $\begin{array}{l}\text { Quartiles energy intake } \\
\text { per } 24 \text { h (HBE requirement) }\end{array}$ & n (\%) & & \\
\hline Adequate intake (90 to $110 \%)$ & $1(0.88)$ & & \\
\hline Inadequate energy intake (0 to $89 \%$ ) & $112(99.12)$ & & \\
\hline $1^{\text {st }}(0$ to $24.9 \%)$ & 79 (69.9) & & \\
\hline $2^{\text {nd }}(25$ to $49.9 \%)$ & $24(21.2)$ & & \\
\hline $3^{\text {rd }}(50$ to $74.9 \%)$ & $8(7.1)$ & & \\
\hline $4^{\text {th }}(75$ to $99.9 \%)$ & $1(0.9)$ & & \\
\hline $5^{\text {th }}(100$ to $124.9 \%)$ & $1(0.9)$ & & \\
\hline \multicolumn{4}{|c|}{ Quartiles zinc intake per $24 \mathrm{~h}$ (ESPEN requirement) } \\
\hline Adequate intake (11-19 mg) & $0(0)$ & & \\
\hline Inadequate intake $(<11 \mathrm{mg})$ & $113(100)$ & & \\
\hline $1^{\text {st }}(0-24.9 \%)$ & $113(100)$ & & \\
\hline $2^{\text {nd }}$ to $5^{\text {th }}(25-124.9 \%)$ & $0(0)$ & & \\
\hline \multicolumn{4}{|c|}{ Quartiles selenium intake per $24 \mathrm{~h}$ (ESPEN requirement) } \\
\hline Adequate intake $(20-70 \mu \mathrm{g})$ & $0(0)$ & & \\
\hline Inadequate intake (<20 $\mu \mathrm{g})$ & $113(100)$ & & \\
\hline $1^{\text {st }}(0-24.9 \%)$ & $113(100)$ & & \\
\hline $2^{\text {nd }}$ to $5^{\text {th }}(25-124.9 \%)$ & $0(0)$ & & \\
\hline
\end{tabular}

*Significant at $p<0.05$

HBE Harris-Benedict Equations, ESPEN European Society for clinical nutrition and metabolism

$55 \%$ while carbohydrate ranges from 30 to $90 \%$ of their total energy [35]. Micro-nutrient daily adequacy for most minerals (zinc and selenium) and vitamins is usually attained with the delivery of enriched commercial tube formula depending on the concentration of the nutrient in focus [1]. Another advantage of CTFs is that some formulations have been developed for specific diseases with controlled nutrient content [18]. The NGTF in this study was more similar to a standard high energy formulae though with low fat content.

Naso-gastric tube feeding has commonly been used in hospitals globally among patients with difficulties in eating due to dysphagia, who do not attain their nutrient adequacy targets [36]. Despite the knowledge of the benefits of using CTF for naso-gastric tube feeding, actual nutrition support received by patients in hospitals has continued to be sub-optimal; both in developed and developing countries, and being worse in the sub-Saharan
Africa [37]. In a meta-analysis, $70 \%$ of articles reviewed that optimal energy intake for critically ill patients ranged from 20 to $35 \mathrm{Cal} / \mathrm{kg} /$ day while protein intake ranged from 0.8 to $2.0 \mathrm{~g} / \mathrm{kg} /$ day [19].

In this study, the finding that nutrient intake of hospital prepared blended feeds for naso-gastric tube feeding did not meet nutrient adequacy among patients on naso-gastric tube feeding was expected considering the variations in nutrient content, volume of feeds administered and the unsuitable feeding mode (bolus gravitational feeding). Further, NGTF delivered to patients had no record of target volumes or nutrient content. Similarly, findings in the Netherlands of $48 \mathrm{~h}$ clinical audit, showed that patients on naso-gastric pump feeding using intermittent and continous feeding modes attained nutrient adequacy within the first day as opposed to the patients who were fed using bolus gravitational feeding $[19,38]$. Similar studies showed a significant proportion 
of patients attained nutrient adequacy within the first day of commercial tube feeding administration [32, 34]. This might have been influenced by the use of pumps in feeding and the use of CTFs.

There are serious consequences when patients do not attain nutrient adequacy early in their course of recovery as reported by a meta-analysis $[9,39,40]$. Increased malnutrition prevalence rates and co-morbidities were reported in patients who had nutrient inadequacy in the 16 articles reviewed [19]. Further, in a study in Nigeria, inpatients were found to have significantly low serum albumin concentration compared to outpatients [41]. The study also showed that low protein intake was common among in-patients, this could have rendered patients being prone to opportunistic illnesses resulting in poor hospital outcomes.

Zambia's Ministry of Health is in the process of developing clinical nutrition guidelines that will inform the provision of quality health care in public hospitals [24]. The findings of this study can provide evidence for some gaps in the service delivery that need to be addressed so as to achieve the goal of quality health care for all Zambians.

The cross-sectional design used by this study may not reveal the change in nutrient intake among the patients over time. It also did not consider a full range of micronutrients. The other limitation in this study was the use of the HB-equations which have been shown to overestimate the energy needs of individuals [28].

\section{Conclusions}

Patients on NGTFs especially those receiving hospital prepared blended foods are at risk for malnutrition as the hospital prepared blended naso-gastric tube feeds contained varying, and inconsistent amounts of carbohydrates, proteins, fat, zinc and selenium, despite being the same volume. The nutrient intake for almost all participants was inadequate for zinc and selenium, with only one patient meeting their energy requirements. It is recommended that CTF be adopted as they have been shown to provide patients with predictable nutrient amounts. Further, the use of naso-gastric feeding pumps for continous and intermittent feeding should be promoted to assure nutrient adequacy.

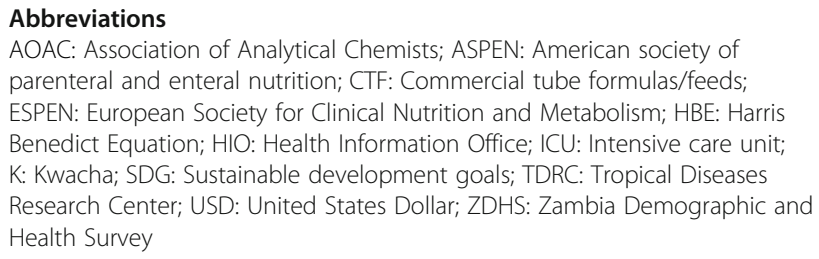

\section{Acknowledgement}

The study was supported by clinicians at Ndola Central Hospital through hospital management authority.

\section{Funding}

The study was supported by a grant from the Irish Aid Fellowship Programme.

\section{Availability of data and materials}

The authors will not share data from the hospital for preservation of patient confidentiality in line with the hospital policy.

\section{Authors' contribution}

MN: Principal investigator, study design, data collection, statistical analyses, and writing. IO: Main supervisor of the study, research coordinator and writing. CN: Supervisor and writing. All authors read and approved the final manuscript.

\section{Competing interests}

The authors declare that they have no competing interest.

\section{Consent for publication}

Not applicable.

\section{Ethics approval and consent to participate}

Ethical clearance was obtained from Kenyatta University Ethics Committee (PKU/415/1384) in Kenya and Tropical Diseases Research Centre (TDRC) Ethics Committee (IRB registration number: 00002911) in Zambia. Authority to collect data was then obtained from the referral hospital's administration in Zambia. Written or thumb printed voluntary informed consent was sought from all participants. For those unable to give consent, their relatives were requested to give informed consent. The participants' privacy and confidentiality was ensured by keeping their filled research questionnaires in a locked cupboard. Further, their names or national identity numbers were not indicated on their questionnaires. Research findings will be disseminated during clinical meetings at the hospital and other relevant forums for the purposes of improving naso-gastric tube feeding practice.

\section{Author details}

'Department of Food, Nutrition and Dietetics, Kenyatta University, P O Box 43844, Nairobi, Kenya. ${ }^{2}$ Internal Medicine Department, Postal Agency, Ndola Central Hospital, Ndola, Zambia.

Received: 20 April 2016 Accepted: 20 October 2016

Published online: 26 October 2016

\section{References}

1. Kreymann KG, Berger MM, Deutz NEP ea, Hiesmayr M, Jolliet P, Kazandjiev $G$, Nitenberg $G$ Berghe $G$, et al. ESPEN guidelines on enteral nutrition: Intensive Care. Clin Nutr. 2006:25(2):210-23.

2. Heyland K, Dhaliwal R, Drover W, Gramlich L, Dodek P. Canadian Clinical guidelines for Nutrition Support in Mechanically Ventilated, Critically III Adult Patients. JPEN J Parenter Enteral Nutr. 2003;27:355-73.

3. Elke G, Wang M, Weiler N, Day A, Heyland D. Close to Recommended Energy and Protein intake by enteralnutrition is associated with better clinical outcome of Critically III Septic patients' Secondary analysis of a large International nutrition database. Crit Care. 2014;18:R29.

4. Pepersack T, Rotsaert P, Benoit F, Willems D, Fuss M, Bourdoux P, Duchateaus. Prevalence of Zinc deficiency and its clinical relevance among hospitalized elderly. Arch Gerentol Geriatr, Elsevier. 2001;243-255.

5. Chan YH, Siu CW, Yiu KH, Chan HT, Li SW, Tam S, Cheung BM, Lau CP, Lam $\mathrm{TH}$, Tse HF. Adverse systemic arterial function in patients with selenium deficiency. J Nutr Health Aging. 2012;16(1):85-88.

6. Valle BL, Falchuk KH. The biochemical basis of zinc physiology. Physiol Rev. 1993;73(1):79-118.

7. Joy E, Kumssa D, Broadley M, Watts M, Young S, Chilimba A, Ander E. Dietary mineral supplies in Malawi: Spatial and Socioeconomic assessment. BMC Nutr. 2015:1:42

8. McClave A, Martindale G, Venek W, McCarthy M, Roberts P, Taylor B, Ochoa B, Napolitano L, Cresc G. Guidelines for the provision and Assessment of Nutrition Support Therapy in the Adult Critically ill Patients: Society of Critical Care Medicine (SCCM) and American Society for Parenteral and Enteral Nutrition (ASPEN). JPEN J Parenter Enteral Nutr. 2009;33:277-316. 
9. Sumantra R, Celia L, Rajna G. Malnutrition in healthcare institutions: A review of the prevalence of under-nutrtition in hospitals and care since 1994 in England. Clin Nutr. 2013;829-835.

10. Agarwal E, Ferguson M, Banks M, Bauer J, Capras S, Isentring E. Nutritional status and dietary intake of acute care patients: results from the Nutrition Care Day Survey 2010. Clin Nutr. 2012;31(1):41-7.

11. Kondrup J, Allison P, Elia M, Vella B, Plauth M. ESPEN Guidelines for Nutrition Screening 2002. Clin Nutr. 2003;22(4):415-21.

12. Mokhalalati JK, Druyan ME, Shott SB, Comer GM. Microbial nutritional and physical quality of Commercial and hospital prepared tube feedings in Saudi Arabia. Saudi Med J. 2004;25(3):331-41.

13. Tanchoco C, Florentino F. Survey of blenderized diets prepared by some hospitals in metro Manilla Phase 2. Nutrient Composition of Blenderized diets. Hospital J. 1990;22:17-26.

14. Sullivan M, Soreda-Esguera P, Planton B, Maria C, Chou N, Shott S, Comer G, Alarcon P. Nutritional analysis of blenderized enteral diets in the phillipines. Asia Pac J Clin Nutr. 2004;13(4):385-90.

15. Gallagher-Allred R. Comparison of institutionally and commercially prepared formulas. Nutr Support Serv. 1983:3:32-4.

16. Elia M, Zellipour $L$, Stranton RJ. To screen or not to screen for adult malnutrition? Clin Nutr. 2005;24(6):867-84.

17. Henderson CT, Trumbore LS, Mobarhan S, Benya R, Mile TP. Prolonged tube feeding in long-term care: nutritional status and clinical outcomes. J Am Coll Nutr. 1992;11(3):309-25.

18. Binnekade JM, Tepaske R, Bruynzeel P, Mathus-Vliengen EM, de Haan RJ. Daily enteral feeding practice on the ICU: attainment of goals and interfering factors. Crit Care. 2005;9(3):1.

19. Lewis J, Egger M, Sylvester A, et al. Early enteral feeding versus "nil by mouth" after gastrointestinal surgery: systematic review and meta-analysis of controlled studies. Br Med J. 2001:323:1-5.

20. Central Statistical Office (CSO), Ministry of Health (MOH) [Zambia], ICF International. Zambia Demographic and Health Survey 2013-14. Rockville: CSO, ICF Inter; 2014

21. Ndola Central Hospital. Nutrition and Dietetics Dept. Ndola Central Hospital Annual Report. Ndola: Ndola Central Hospital, Ministry of Health; 2015.

22. Burgos R, Sarto E, Planas M, Forga M, Canton A, et al. Prevalence of malnutrition and its etiological factors in hospitals. Nutr Hosp. 2012;2(27):469-76.

23. Katzenellenbogen JM, Joubert G, Abdool Karim SS. Epidemiology: A manual for South Africa. Cape Town: Oxford University Press Southern Africa; 2002.

24. Government Republic of Zambia. National Health Policy. Lusaka: Ministry of Health; 2012.

25. Bartlett JE, Kotrilik JW, Higgins CC. Organizational Research: Determining Appropriate sample size in Survey Research. Inf Technol, Learn Performa; 2001;19(1):43.

26. Israel. Determining sample size. University of Florida. Gainesville: IFAS Extension; 2013. p. 3-5.

27. Elliott P, Peakman TC. The UK Biobank sample handling and storage protocol for the collection, processing and archiving of human blood and urine. Int J Epidemiol. 2008:37(2):234-44.

28. Picolo MF, Lago AF, Menegueti MG, Nicolini EA, Basile-Filho A, Nunes AA, Martins-Filho OA, Auxiliadora-Martins M. Harris-Benedict equation and resting energy expenditure estimates in critically ill ventilator patients. Am J Crit Care. 2016:25(1):e21-9.

29. Khalid I, Doshi P, Digiovine B. Early enteral nutrition and outcomes of critically ill patients treated with vasopressors and mechanical ventilation. Am J Crit Care. 2010;19:261-8.

30. Elke $\mathrm{G}$, Wang $\mathrm{M}$, Weiler $\mathrm{N}$. Close to recommended energy and protein intake by enteral nutrition is associated with better clinical outcome of critically ill septic patients: Secondary analysis of a large international nutrition database. Crit Care. 2014;18:R29.

31. Horwitz W. Official Method of analysis of AOAC international. 17th ed. Maryland: AOAC International; 2000.

32. Barton A, Beigg C, Macdonald A, Allison S. High food wastage and low nutritional intakes in hospital patients. Clin Nutr. 2000;19:445-9.

33. Parrish C, Arlene E. Blenderized Tube Feeding: Suggested Guidelines to Clinicians. Pract Gastroenterol. 2014;136:58-66.

34. American Society for Parenteral and Enteral Nutrition. Standards for nutrition support: hospitalized patients. Nutr Clin Pract. 1995;10:208-19.

35. Trabal J, Leyes P, Forga MT, Hervas S. Quality of life, dietary intake and nutritional status assessment in hospital admitted cancer patients. Nutr Hosp. 2006;21(4):505-510.
36. Dhaliwa R, Drover J, Muscedere J, Jiang X, Heyland K. Feeding enterally the hemodynamically unstable critically ill patients: experience from a multicenter trial (the REDOX study). Crit Care. 2009;13(suppl1):p144.

37. Braunschweig C, Gomez S, Shean P. Impact of declines in nutritional status on outcomes in adult patients hospitalized for more than 7 days. J Am Diet Assoc. 2000;100(11):1316-22.

38. Government of the Republic of Zambia, National Food and Nutrition Commission. National Food and Nutrition Strategic Plan for Zambia 2011-2015. Lusaka: GRZ; 2011.

39. Lansey S, Waslien C, Mulvihill M, Fillit $H$. The role of anthropometry in the assessment of malnutrition in the hospitalized frail elderly. Gerontology. 1993:39:346-53.

40. Collen M, O'leary K, Kathleen P, Juliana B, Nancy S, Marilyn D. Nutritional adequacy in patients receiving mechanical ventilation who are fed enterally. Am J Crit Care. 2005;14(2):222-31.

41. Akuyam A, Anaja O, Aliyu S, Mai A, Dahiru L. Serum albumin as a rough guide to the assessment of nutritional status of hospitalized patients: A study from Zaria, Northen Nigeria. Int J Med Med Sci. 2013;30-34.

\section{Submit your next manuscript to BioMed Central and we will help you at every step:}

- We accept pre-submission inquiries

- Our selector tool helps you to find the most relevant journal

- We provide round the clock customer support

- Convenient online submission

- Thorough peer review

- Inclusion in PubMed and all major indexing services

- Maximum visibility for your research

Submit your manuscript at www.biomedcentral.com/submit
) Biomed Central 